55(suppl 2):S122-S130.

12. Lautt WW. Autonomic neural control of liver glycogen metabolism. Med Hypotheses. 1979; 5(12):1287-1296.

13. Sakaguchi T, Bray GA. Sympathetic activity following paraventricular injections of glucose and insulin. Brain Res Bull. 1988;21(1):25-29.

14. Spanswick D, Smith MA, Mirshamsi S, Routh VH, Ashford ML. Insulin activates ATP-sensitive K+ channels in hypothalamic neurons of lean, but not obese rats. Nature Neurosci. 2000;3(8):757-758.

15. Kang L, Routh VH, Kuzhikandathil EV, Gaspers L, Levin BE. Physiological and molecular characteristics of rat hypothalamic ventromedial nucleus glu- cosensing neurons. Diabetes. 2004;53(3):549-559.

16. Lin HV, et al. Diabetes in mice with selective impairment of insulin action in glut4-expressing tissues. Diabetes. 2011;60(3):700-709.

17. Konner AC, et al. Insulin action in AgRP-expressing neurons is required for suppression of hepatic glucose production. Cell Metab. 2007;5(6):438-449.

18. Lin HV, et al. Divergent regulation of energy expenditure and hepatic glucose production by insulin receptor in agouti-related protein and POMC neurons. Diabetes. 2010;59(2):337-346.

19. Bruning JC, et al. Role of brain insulin receptor in control of body weight and reproduction. Science. 2000;289(5487):2122-2125.
20. Mullier A, Bouret SG, Prevot V, Dehouck B. Differential distribution of tight junction proteins suggests a role for tanycytes in blood-hypothalamus barrier regulation in the adult mouse brain. J Comp Neurol. 2010;518(7):943-962.

21. Gerozissis K, Rouch C, Lemierre S, Nicolaidis S, Orosco M. A potential role of central insulin in learning and memory related to feeding. Cell Mol Neurobiol. 2001;21(4):389-401.

22. Sindelar DK, Balcom JH, Chu CA, Neal DW, Cherrington $\mathrm{AD}$. A comparison of the effects of selective increases in peripheral or portal insulin on hepatic glucose production in the conscious dog. Diabetes. 1996;45(11):1594-1604.

\title{
Finally! A human pancreatic $\beta$ cell line
}

\author{
Gordon C. Weir and Susan Bonner-Weir
}

Section on Islet Cell Biology and Regenerative Medicine, Research Division, Joslin Diabetes Center, and Department of Medicine, Harvard Medical School, Boston, Massachusetts, USA.

\begin{abstract}
For decades, investigators have made numerous attempts to generate human pancreatic $\beta$ cell lines that could be used to advance $\beta$ cell biology, facilitate drug discovery, and provide a pathway to $\beta$ cell replacement therapy for the treatment of diabetes. In this issue of the JCI, Ravassard and colleagues report that this has finally been achieved successfully with a multistep process that led to the generation of cells, which they termed EndoC- $\beta H 1$ cells, that secreted insulin in response to glucose challenge.
\end{abstract}

The pancreas is a complex organ with endocrine and exocrine compartments. The endocrine compartment consists of $\alpha, \beta$, $\delta$, and pancreatic polypeptide cells, which produce glucagon, insulin, somatostatin, and pancreatic polypeptide, respectively. These cells are organized into islets of Langerhans, which are scattered throughout the exocrine pancreas. Loss of pancreatic $\beta$ cell function as a result of autoimmune-mediated destruction and failure of pancreatic $\beta$ cells to produce enough insulin to meet the body's demands result in type 1 and type 2 diabetes, respectively.

Even though $\beta$ cells are the predominant cell type within islets of Langerhans, they comprise approximately $1 \%-2 \%$ of total pancreatic cells only. Isolating a homogenous population of $\beta$ cells has therefore proven difficult, hampering studies of human pancreatic $\beta$ cell physiology as well as studies of the pathogenesis of diabetes and the development of therapeutics - both pharmacologic and cell based - to treat diabetes. Many questions pertinent to these issues could be addressed

Conflict of interest: The authors have declared that no conflict of interest exists.

Citation for this article: J Clin Invest. 2011; 121(9):3395-3397. doi:10.1172/JCI58899. by studies using a human pancreatic $\beta$ cell line. Despite decades of attempts by many, human pancreatic $\beta$ cell lines that retain the characteristics of primary $\beta$ cells remain unavailable. However, in this issue of the JCI, Ravassard and coworkers report that they have finally succeeded in generating a cell line from human pancreatic $\beta$ cells (which they named EndoC- $\beta$ H1) that maintains many of the characteristics of primary mature $\beta$ cells (1).

\section{Lessons from 30 years of work in rodents}

When developing a strategy to generate a human pancreatic $\beta$ cell line, Ravassard and colleagues clearly took to heart lessons from the development of rodent cell lines. The generation of rodent pancreatic $\beta$ cell lines followed several decades of work in which several steps of the process were developed. In one of the earliest pertinent studies, it was found that an insulin-producing pancreatic tumor, which appeared after irradiation of rats, could be propagated as a transplantable insulinoma (2). After this, a way was found to passage these insulinoma cells in vitro as RIN cells $(3,4)$. These cells exhibited some phenotypic instability, as clones contained variable amounts of insulin and the $\delta$ cell product somatostatin. Nonetheless, some of the subcloned cell lines had a stable enough phenotype to have important research value. The next advance was achieved with cells from the same transplantable insulinoma, with the finding that treatment of the cells with 2-mercaptoethanol, which maintained glutathione levels, resulted in the generation of cells (known as INS1 cells) that had impressively improved insulin content relative to the insulinoma cells and superior ability to secrete insulin following stimulation with glucose, a phenotype resembling primary pancreatic $\beta$ cells (5). Further improvements of INS1 cells in terms of insulin content and secretion were then obtained with clonal selection techniques to obtain a cell line called $823 / 13$ (6). In work going on in parallel, the oncogene simian virus 40 large tumor antigen (SV40LT) was first used to make cells with $\beta$ cell characteristics when HIT cells were generated from infected isolated islets from hamsters (7). Work in mice with the same oncogene then led to the generation of $\beta$ TC cells (8) and MIN6 cells (9), which remain among the most widely used rodent pancreatic $\beta$ cell lines today.

\section{A multistep process starting with human fetal pancreas}

The remarkable achievement of Ravassard and colleagues was accomplished by starting with fetal pancreatic buds (1) (Figure 1). These were transduced with a lentiviral vector expressing SV40LT under the control of the insulin promoter and then transplanted into SCID mice to allow expansion of the transformed $\beta$ cells to proceed over 


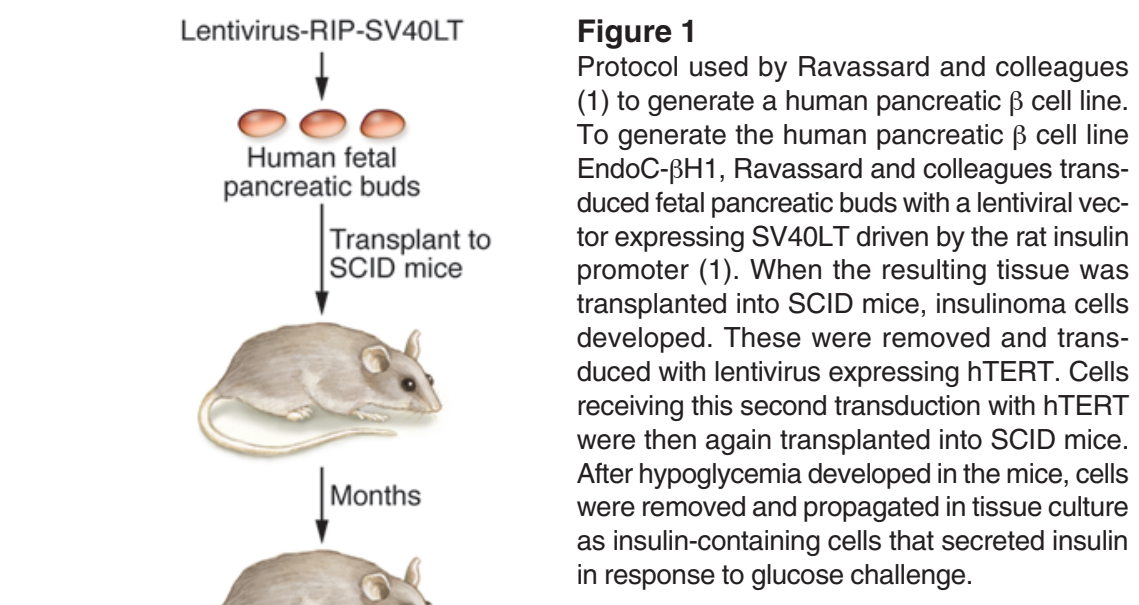

pancreatic polypeptide. Curiously, however, there were rare cells that costained for insulin and somatostatin, although the significance of these cells is unknown. The key step in this protocol that led to the successful generation of a human pancreatic cell line appears to be the expression of SV40LT in $\beta$ cells from fetal pancreas, which resulted in the generation of insulinomas in an in vivo transplant site. Notably, this strategy did not succeed with adult human islets. The contribution of hTERT remains to be determined, but it may have enhanced the longevity and stability of the resultant cell line.

\section{Caveats with studies of clonal and primary islet cells}

We can expect the human pancreatic cell line generated by Ravassard and colleagues (1) and future human $\beta$ cell lines to be a boon for $\beta$ cell biology, as was the case with rodent cell lines. However, it is important to not forget the shortcomings of all $\beta$ and other islet cell lines. They are not primary islet cells, and even primary islet cells have significant complexities that confound interpretation of studies but are often not appreciated. Even in their in vivo home in the pancreas, $\beta$ cells are heterogeneous (10). They differ in age; for example, there are big functional differences between newly formed $\beta$ cells and fully mature cells (11). No doubt there must be other forces, such as local environment and interactions among different islet cell types, that contribute to differences in phenotype. The ability to isolate islets with enzymatic digestion has been an enormously important tool for studying pancreatic $\beta$ cells, but there too are caveats. $\beta$ Cells within these isolated islets are hypoxic if centrally located in large islets (12) and are no doubt flooded with locally released glucagon and somatostatin, which occurs to a far lesser extent in vivo due to compartmentalization of the flow of blood and interstitial fluid through islets (13). With isolated human islets, the same problems are faced along with additional challenges. Even the preparations used for clinical transplantation are far from pure, containing only about 35\% $\beta$ cells, and many cells in any fresh preparation are either dead or dying (14).

Despite all of their limitations, human $\beta$ cell lines such as that generated by Ravassard and colleagues (1) can be expected to be valuable for answering a wide variety of important questions relevant to human pancreatic $\beta$ cell physiology and pathology. As with all good experimental models, valuable data carefully interpreted can lead us to what we are really after, information that will have an impact on understanding the pathogenesis of diabetes and further the development of pharmacologic and cell-based therapies. However, when working with these cells, it will be important to keep in mind that even at their best, the insulin content of the EndoC- $\beta \mathrm{H} 1$ cells was less than $10 \%$ that of normal $\beta$ cells, which is not as good as some rodent $\beta$ cell lines. Another point is that these cells must be closely monitored as they are passaged to determine how well they maintain their $\beta$ cell characteristics and to be sure that cells with the phenotype of other islet cell types do not emerge.

\section{Where this advance may lead}

This initial success of Ravassard and colleagues (1) could lead to the production of even more valuable cells. Certainly, attempts will be made to use the same strategy but with conditional expression of SV40LT and hTERT, such that after cell expansion, expression of the genes can be removed. Based upon success using a similar strategy of conditional expression of SV40LT in a mouse cell line (15), it is reasonable to expect that this will produce a more "normal" $\beta$ cell phenotype, with higher insulin content and more exuberant insulin secretion in response to glucose stimulation. In theory, this could generate unlimited numbers of true $\beta$ cells. Thus, this genetic engineering approach could compete with the impressive progress made using directed differentiation of human embryonic stem cells (16) and induced pluripotent stem cells (17) to create fully mature $\beta$ cells. Solving the problem of inadequate $\beta$ cell supply would have enormous implica- 
tions for experimental islet biology, understanding of disease pathogenesis, drug discovery, and $\beta$ cell-replacement therapy for both type 1 and type 2 diabetes; the work of Ravassard and colleagues (1) takes us a step closer toward solving this problem.

\section{Acknowledgments}

This work was supported by grants from the NIH (RC4 DK090781 and R01 DK066056), the Juvenile Diabetes Research Foundation, and the Diabetes Research and Wellness Foundation.

Address correspondence to: Gordon C. Weir, Section on Islet Cell Biology and Regenerative Medicine, Joslin Diabetes Center, One Joslin Place, Boston, Massachusetts 02215, USA. Phone: 617.732.2581; Fax: 617.732.2650; E-mail: gordon.weir@joslin. harvard.edu.

1. Ravassard P, et al. A genetically engineered human pancreatic $\beta$ cell line exhibiting glucose- inducible insulin secretion. J Clin Invest. 2011; 121(9):3589-3597.

2. Chick WL, Warren S, Chute RN, Like AA, Lauris $\mathrm{V}$, Kitchen KC. A transplantable insulinoma in the rat. Proc Natl Acad Sci U S A. 1977;74(2):628-632.

3. Gazdar AF, et al. Continuous, clonal, insulin- and somatostatin-secreting cell lines established from a transplantable rat islet cell tumor. Proc Natl Acad Sci US A. 1980;77(6):3519-3523.

4. Oie HK, Gazdar AF, Minna JD, Weir GC, Baylin SB. Clonal analysis of insulin and somatostatin secretion and L-dopa decarboxylase expression by a rat islet cell tumor. Endocrinology. 1983;112(3):1070-1075.

5. Asfari M, Janjic D, Meda P, Li G, Halban PA, Wollheim CB. Establishment of 2-mercaptoethanoldependent differentiated insulin-secreting cell lines. Endocrinology. 1992;130(1):167-178.

6. Hohmeier HE, Mulder H, Chen G, Henkel-Rieger R, Prentki M, Newgard CB. Isolation of INS-1-derived cell lines with robust ATP-sensitive $\mathrm{K}+$ channeldependent and -independent glucose-stimulated insulin secretion. Diabetes. 2000;49(3):424-430.

7. Santerre RF, et al. Insulin synthesis in a clonal cell line of simian virus 40-transformed hamster pancreatic beta cells. Proc Natl Acad Sci U S A. 1981; 78(7):4339-4343.

8. Efrat S, Leiser M, Surana M, Tal M, Fusco-Demane $\mathrm{D}$, Fleischer N. Murine insulinoma cell line with normal glucose-regulated insulin secretion. Diabetes. 1993;42(6):901-907.
9. Miyazaki J, et al. Establishment of a pancreatic beta cell line that retains glucose-inducible insulin secretion: special reference to expression of glucose transporter isoforms. Endocrinology. 1990;127(1):126-132.

10. Pipeleers D, Kiekens R, Ling Z, Wilikens A, Schuit F. Physiologic relevance of heterogeneity in the pancreatic beta-cell population. Diabetologia. 1994; 37(suppl 2):S57-S64.

11. Jermendy A, et al. Rat neonatal beta cells lack the specialised metabolic phenotype of mature beta cells. Diabetologia. 2011;54(3):594-604.

12. Dionne KE, Colton CK, Yarmuch ML. Effect of hypoxia on insulin secretion by isolated rat and canine islets of Langerhans. Diabetes. 1993;42(1):12-21.

13. Bonner-Weir S, Orci L. New perspectives on the microvasculature of the islets of Langerhans in the rat. Diabetes. 1982;31(10):883-939.

14. Pisania A, et al. Quantitative analysis of cell composition and purity of human pancreatic islet preparations. Lab Invest. 2010;90(11):1661-1675.

15. Fleischer N, et al. Functional analysis of a conditionally transformed pancreatic beta-cell line. Diabetes. 1998;47(9):1419-1425.

16. Kroon E, et al. Pancreatic endoderm derived from human embryonic stem cells generates glucoseresponsive insulin-secreting cells in vivo. Nat Biotechnol. 2008;26(4):443-452.

17. Zhang D, et al. Highly efficient differentiation of human ES cells and iPS cells into mature pancreatic insulin-producing cells. Cell Res. 2009;19(4):429-438. 